\title{
INFLUENCE OF HUMAN RESOURCE MANAGEMENT PRACTICES ON EMPLOYEE ENGAGEMENT IN DEVELOPING ECONOMY
}

\author{
Shaheen Ahmed \\ School of Business, Bangladesh Open University, Bangladesh. \\ Email-shaheenmahmed@yahoo.com \\ Sheikh Rafiqul Islam \\ Department of Marketing, Jagannath University, Bangladesh
}

\begin{abstract}
Employee engagement is considered as a vital issue to the practitioners for smooth operations of their business concerns. Thus, the study is conducted to measure the influence of Human Resource Management (HRM) practices as an antecedent of employee engagement. This study collected data from 392 operational level employees through survey method who is working at different garment factories in Bangladesh. The collected data were analyzed through structural equation modeling to partial least square method. The study empirically proves that employee compensation and employee promotion opportunity have significant influence on the employees' engagement level. This study has both theoretical and practical implications in the context of ready-made garment industry in Bangladesh since employee engagement regarded as comparatively new concept in the developing context. The practitioners and policy makers of the organization are expected to make necessary adjustments in their existing HRM practices on the basis of the results of this model in the context of developing economy like Bangladesh for enhancing the employee engagement level so that their whole-hearted efforts can be ensured for the smooth operations of business.
\end{abstract}

Keywords: compensation, developing economy, employee engagement, human resource management practices, promotion opportunity. 


\section{Introduction}

Employee engagement is regarded as an important issue to the practitioners as well as academicians since it has enormous positive influences for achieving the target of the organization. The concept of employee engagement was first imagined by Kahn (1990), however, it receives considerable acceptance from the mid of last decade. Kahn (1990) considers employee engagement in performing the job duties in such a way where employees employ their physical, cognitive and emotional connection. Shuck and Wollard (2010) consider employee engagement as cognitive, emotional and behavioral state of employees which leads employees to achieve organization's desired outcomes. Nevertheless, Shuck, Rocco and Albornoz (2011) find a link between Maslow's (1943) motivation theory and Kahn's (1990) employee engagement concept. Therefore, few sociologists concluded that Kahn's concept was badly dominated by the theorists of motivation (Shuck \& Wollard, 2010).

The Gallup researcher Fleming and Asplund (2007) describe employee engagement as a weapon which inspires them to perform work by devoting their head, heart and soul that are essential in gaining excellent work efforts. A couple of studies reveal that employee engagement is comparatively new concept thus seeks thorough investigation in different contexts for it generalization (Rana, Ardichvili \& Tkachenko, 2014; Solomon \& Sridevi, 2010). Hence, in the context of developing economy like Bangladesh this study considers human resource management (HRM) practices as an antecedent of employee engagement at the workplace. The studies in different countries reveal that 48 percent employees are engaged with the work in USA, 32 percent in China (Gullap Organization, 2013). The study of Aon Hewitt (2013) finds that 40 percent employees are engaged with the work while 20 percent are actively disengaged in the developed country.

In Bangladesh, the ready-made garment (RMG) industry is occupied with about 4.00 million employees which is about 40 percent of total manufacturing employees in the country. In addition, the export earnings of RMG industry are about 82 percent (Export Promotion Bureau, 2017) and contribute to the GDP by 13 percent (Wikipedia, 2015). Moreover, the government of Bangladesh is expecting to flourish its economy by industrialization than traditional agriculture based activities (Ahmed, Ahmad \& Jaaffar, 2017). Thus, the study of employee engagement on the employees of RMG industry deemed essential since it covers majority of the manufacturing workforces. Furthermore, assessing the precursors of employee engagement is expected to assist practitioners so that they can take initiatives to improve engagement level of the 
garment employees. Engagement of employees to the organization not only ensures their whole-hearted efforts but also makes them enthusiastic in performing their job.

Recently, the study of Shuck and Rocco (2014) opine that HRM practices have positive influence on the employees' engagement level in the organization. Their study emphasizes on training and development, career opportunity, participation in organizational decision making process as a HRM practices that are inevitable for improving employee engagement level. In fact, HRM practices have a driving force that makes employees engaged with the work. Several studies in the developed context reveal that practitioners and policy makers are making necessary adjustment on HRM practices in their organization getting employees' more engaged with the work (Arakawa \& Greenberg, 2007; Wagner \& Harter, 2006; Luthans \& Peterson, 2002). Inappropriate HRM practices in the organization increase employees' disengagement level in the organization. Therefore, the aim of this study is to assess the HRM practices such as employee compensation and employee promotion opportunity as antecedents of employee engagement in the context of a developing country particularly in the ready-made garment industry in Bangladesh.

The theoretical framework of this study is given in the figure 1 below:

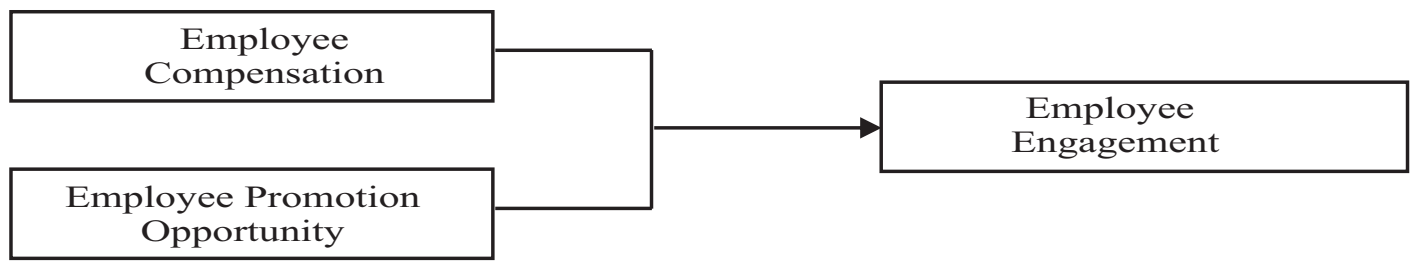

Figure 1: The theoretical framework of the study

\section{Literature review}

\subsection{Relationship between employee promotion opportunity and employee engagement}

The study in the developed economy empirically proved that employees' positional growth has significant relationship with their level of engagement at the workplace (Zhou, Yu \& Cao, 2015). In the Kenyan perspective, Mokaya and Kipyegon (2014) find significant relationship between employees' career growth opportunity and engagement. Anitha (2014) confirms in Asian perspective that employee promotion opportunity and fairness in promotion policy are essential to make employees engaged with their work at the workplace. Furthermore, Choo et al. (2013) realizes in their study that employee engagement culture will prevails in the organization when promotion opportunities of the employees are ensured. 
According to Coetzee and Villiers (2010), work engagement level of the employees is improved when they perceived that the opportunity of career goal attainment can be realized by serving the organization. Schaufeli and Salanova (2010) point out from their study that career advancement programs intended employees toward personal growth which, in turn, enhance employee engagement level in their job. Fleck and Inceoglu (2010) in their "person-job fit and person-organization fit engagement model" propose that employee engagement is highly dominated by career prospect; and this finding also supported by Albrecht (2010), and Gagne and Bhave (2011). Employees' mental attachment with the job decreases geometrically when they deprive of from promotion opportunity.

\subsection{Relationship between employee compensation and employee engagement}

The empirical study of Koskey and Sakataka (2015) find positive relationship between handsome compensation and employees' high engagement level. Furthermore, in the perspective of Pakistan, Iqbal, Karim and Haider (2015) find significant relationship between well-designed compensation package and employees' level of engagement. Additionally, Crawford, Brown, Kvangarsnes and Gilbert (2014) find that compensation is one of the key antecedents which inspire employees' to be engaged in their work.

The study of Choo et al. (2013) on the front-desk employees in Malaysia shows that compensation is one of the good predictors that increase employees' engagement level at their workplace. Moreover, Wollard and Shuck (2011), and Solomon and Sridevi (2010) report that rewards are positively correlated with the level of employees' work engagement. If employees are given their desired compensation package they will be highly engaged with the work, they added. Furthermore, Joshi and Sodhi (2011), in the context of India, reveal that employee engagement is the outcome of compensation or other monetary benefits employee received from the organization.

\section{Objectives of the study}

The main objective of this study is to assess the influence of HRM practices on the employees' engagement level. More specifically, the present study secures the following objectives: 
- To measure the influence of employee promotion opportunity on the employee engagement.

- To measure the influence of employee compensation on the employees' engagement level.

\section{Hypotheses of the study}

Based on the previous studies the present study generates two hypotheses such as:

H1: Employee promotion opportunity has positively influence on the employees' engagement level.

H2: Employee compensation has positively influence on the employees' engagement level.

\section{Methodology of the study}

The study has been conducted on the operational level employees of different garment factories at Ashulia area of Dhaka division in Bangladesh. The respondents were selected randomly to collect their opinions regarding employee promotion opportunity, employee compensation, and employee engagement. In Ashulia area about 0.40 million employees are working at different garment factories (Ahmed, Ahmad \& Jaaffar, 2017), therefore, data were collected from 392 (Sekeran, 2006; Krejcie \& Morgan, 1970) on-job lower level employees working at different factories holding positions such as sewing operators, washing man, iron man, packing man and helper. The male and female respondents of this study were 13 percent and 87 percent respectively and are selected by using simple random sampling method.

In multivariate analysis, the sample size is recommended 5 times of the items of the questionnaire in getting satisfactory results (Roscoe, 1975). Therefore, responses of 90 respondents is enough for this study, nonetheless, the more the sample size the more the reliable results are produced (Cornish, 2002). Thus, this study is performed considering the opinion of 392 respondents.

The questionnaire of this study is consisted of with 18 items adapted from previously developed by different scholars and are used in different studies in different contexts. The items of employee compensation, employee promotion opportunity and employee engagement have been adapted from Tessema and Soeters (2006), Price and 
Mueller (1986), and Schaufeli, Bakker and Salanova (2006) respectively. The reliability of the items of compensation, promotion opportunity and employee engagement are $0.867,0.804$ and 0.841 respectively. For the collection of data the questionnaire were designed by using 7-point Likert measurement scale because it is easy to construct as well as more appealing and respondents have more freedom to make their opinions comfortably (Hinkin, 1995).

The collected data were analyzed through structural equation modeling (SEM) with the help of partial least square (PLS) method commonly known as PLS-SEM. In PLSSEM path modeling technique, the data are analyzed through the assessment of outer model and inner model. PLS-SEM is regarded as second generation statistical tools that produces results from different perspectives and provides more reliable results for the study.

\section{Results and analyses}

The results of the study are presented through the assessment of outer model and inner model.

\subsection{Assessment ofouter Mmodel}

The outer model assesses the quality of the constructs as well as the indicators of the path model and the relationship between the constructs and their respective items. In PLS-SEM path modeling, items and constructs of the study come through the fulfillment of quality parameter therefore, produce reliable results that have influence on the exogenous construct. The beta values of promotion opportunity and compensation with employee engagement are 0.253 and 0.419 respectively signifies positive relationship.

Table 1: Quality criteria assessment for the constructs and observed variables

\begin{tabular}{l|l|l|l|c}
\hline \multicolumn{1}{c|}{ Constructs } & $\begin{array}{c}\text { Observed } \\
\text { Variables }\end{array}$ & $\begin{array}{c}\text { Outer } \\
\text { Loadings }\end{array}$ & $\begin{array}{l}\text { Composite } \\
\text { Reliability }\end{array}$ & $\begin{array}{l}\text { Average Variance } \\
\text { Extracted (AVE) }\end{array}$ \\
\hline Employee Promotion & PRO_1 & 0.797 & & \\
Opportunity & PRO_2 & 0.772 & 0.823 & 0.538 \\
& PRO_3 & 0.720 & & \\
& PRO_4 & 0.686 & & \\
\hline
\end{tabular}




\begin{tabular}{l|l|l|l|l}
\hline Employee Compensation & COM_1 & 0.758 & & \multirow{2}{*}{0.514} \\
& COM_3 & 0.728 & 0.808 & \\
& COM_4 & 0.719 & & \\
\hline \multirow{2}{*}{ Employee Engagement } & COM_5 & 0.729 & & \multirow{2}{*}{0.555} \\
& ENG_1 & 0.727 & & \\
& ENG_3 & 0.733 & \multirow{2}{*}{0.833} & \\
& ENG_6 & 0.723 & & \\
\hline
\end{tabular}

The association between construct and its respective items is assessed by the outer loadings statistically known as indicator reliability that identifies the portion of an indicator's variance explained by the latent construct. The loadings below 0.4 are suggested to be deleted from the model (Hair, Ringle \& Sarstedt, 2011) to ensure the quality of the indicators. In addition, the item deletion remain continued if deletion process have influence on the increase of AVE at least 0.5 level.

Traditionally, Cronbach's alpha value is measured to test the reliability of the variables; however, composite reliability is assessed to see whether constructs are reliable in PLS-SEM path modeling. The threshold value of composite reliability is 0.6 , nonetheless, the values more than 0.6 signifies that the constructs are more reliable. In addition, convergent validity is measure to see the correlation between the indicators of the same construct. Convergent validity is assessed by the value of average variance extracted (AVE) which should not be less than 0.5 to gain the acceptability.

\section{Discriminant validity}

Discriminant validity assesses the dissimilarities of the constructs in the model through the empirical standard. Although three methods are available for the measurement of discriminant validity the Fornell-Larcker criterion is widely used technique for making decision. 
Table 2: Latent variable correlations and square roots of AVE (Fornell-larcker criterion)

\begin{tabular}{l|c|c|c}
\hline \multicolumn{1}{c|}{ Constructs } & $\begin{array}{c}\text { Employee } \\
\text { Engagement }\end{array}$ & $\begin{array}{c}\text { Employee } \\
\text { Engagement }\end{array}$ & $\begin{array}{l}\text { Employee Promotion } \\
\text { Opportunity }\end{array}$ \\
\hline Employee Compensation & 0.734 & & \\
Employee Engagement & 0.534 & 0.717 & 0.745 \\
Employee Promotion Opportunity & 0.665 & 0.590 & \\
\hline
\end{tabular}

According to Fornell-Larcker criterion, the lower correlations between the constructs than the correlation of the same constructs signifies that there is no problem with discriminant validity. The diagonal values are the correlation between the same constructs whereas the other values are the correlation between the constructs. Thus, from the above table, it ensures that there is no problem with the discriminant validity.

\subsection{Assessment of inner model}

The inner model assesses the relationship between exogenous and endogenous constructs to see whether the model's paths are statistically significant or not. It assists to come to a conclusion about the hypotheses developed in the model.

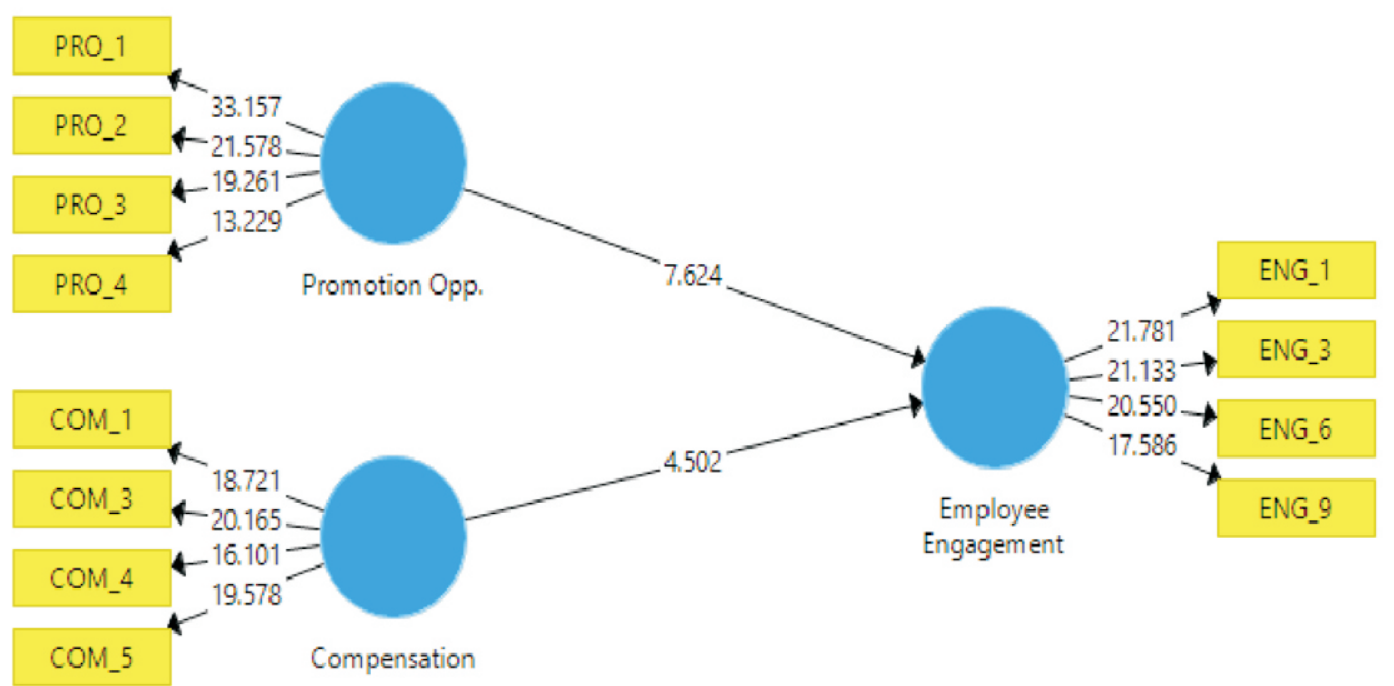

Figure 2: The inner model 


\section{Path coefficients}

The path coefficients reveal the different paths relationship of exogenous and endogenous constructs with respective t-value and p-value that measure whether the said relationship path is statistically significant or not in the model. The table below depicts that all the hypothesized path relationships are statistically significant at $\mathrm{p}=0.001$ level.

Table 3: Assessment of path coefficients

\begin{tabular}{l|l|l|l|l|l}
\hline \multicolumn{1}{c|}{ Paths } & $\begin{array}{c}\text { Original } \\
\text { Sample (O) }\end{array}$ & $\begin{array}{c}\text { Sample } \\
\text { Mean (M) }\end{array}$ & $\begin{array}{l}\text { Standard } \\
\text { Deviation } \\
\text { (STDEV) }\end{array}$ & $\begin{array}{c}\text { T Statistics } \\
(\mid \mathbf{O} / \text { STDEV|) }\end{array}$ & $\begin{array}{c}\text { P } \\
\text { Values }\end{array}$ \\
\hline $\begin{array}{l}\text { Compensation -> Employee } \\
\text { Engagement }\end{array}$ & 0.254 & 0.253 & 0.253 & 4.502 & 0.000 \\
$\begin{array}{l}\text { Promotion Opp. -> Employee } \\
\text { Engagement }\end{array}$ & 0.421 & 0.419 & 0.419 & 7.624 & 0.000 \\
\hline
\end{tabular}

The above table reveals that when employees of the organization perceive that they are getting desired compensation for their work at the workplace they are expected to be engaged more with the organization. Similarly, employees' positive perception about the opportunity of getting promotion in the organization make them more engaged with the work in the organization.

\section{Coefficient of determination $\left(R^{2}\right)$}

Coefficient of determination assesses the variances explained by the exogenous constructs for the endogenous construct. The exogenous constructs (employee compensation and employee promotion opportunity) together explains 38.4 percent of the variances for the exogenous construct (i.e., employee engagement). The table below represents the variances explained in this model.

Table 4: Variance explained for exogenous latent constructs

\begin{tabular}{c|l}
\hline Construct & Variance Explained $\left(\mathrm{R}^{2}\right)$ \\
\hline Employee Engagement & 0.384 \\
\hline
\end{tabular}




\section{Assessing predictive relevance $\left(Q^{2}\right)$}

The predictive relevance measures the accuracy of the model through the construct cross-validated redundancy. The predictive relevance measures what the model predict for the study. Usually, the Q2 value signifies that the model has good predictive relevance when the values becomes more than zero of the study. The table 5 represents the value of cross-validated redundancy for the assessing the predictive relevance of the model of this study.

Table 5: Construct cross-validated redundancy

\begin{tabular}{l|c|c|c}
\hline \multicolumn{1}{c|}{ Constructs } & SSO & SSE & $\mathbf{Q}^{2}$ (=1-SSE/SSO) \\
\hline Employee Compensation & $1,568.000$ & $1,568.000$ & \\
Employee Engagement & $1,568.000$ & $1,293.363$ & 0.175 \\
Employee Promotion Opportunity & $1,568.000$ & $1,568.000$ & \\
\hline
\end{tabular}

The above table reveals predictive relevance by 17.5 percent for this model, thus ensure good predictive power. The employee compensation and promotion opportunity together have positive effect on the employees' level of engagement in the organization.

\section{Table 6: Results of hypotheses}

\begin{tabular}{c|l|c}
\hline H & \multicolumn{1}{|c}{ Statements } & \multicolumn{1}{|c}{ Decision } \\
\hline H1 & $\begin{array}{l}\text { Employee promotion opportunity has positively influence on the } \\
\text { employees' engagement level. }\end{array}$ & Supported \\
H2 & $\begin{array}{l}\text { Employee compensation has positively influence on the employees' } \\
\text { engagement level. }\end{array}$ & Supported \\
\hline
\end{tabular}

The above table reveals predictive relevance by 17.5 percent for this model, thus ensure good predictive power. The employee compensation and promotion opportunity together have positive effect on the employees' level of engagement in the organization. 


\section{Discussion}

The outer model assesses the quality requirements of this study through the examination of constructs reliability and validity. Traditionally, Cronbach's alpha value more than 0.6 is considered for ensuring the reliability of the variables (Nunally $\&$ Bernstein, 1994), nevertheless, the composite reliability and convergent validity are more acceptable due to some limitations of Cronbach's alpha value for the assessment of constructs reliability followed in PLS-SEM technique. The composite reliability value more than 0.6 (Vinzi et al., 2003) and convergent validity value more than 0.50 (Rodgers \& Pavlou, 2003) are acceptable for the study meaning that the constructs are valid and are reliable for getting reliable results. Again, discriminant validity is assessed to see whether the exogenous constructs are mutually exclusive or not. The discriminant validity can be measured through three methods such as Fornell-Larcker criterion, cross loadings and Heterotrait-Monotrait ratio but in this study FornellLarcker criterion is applied as it widely used method. The discriminant validity signifies that each predictor variable has separate predictive power and not mutually exclusive. The results of all quality criteria satisfy the respective threshold value thus ensure the quality of the constructs of this model.

The initial items loadings become more than 0.4 , however, the item deletion process is administered for getting the AVE (average variance extracted) value at least 0.5 or more (Hair et al., 2014) since VB-SEM (variance based structural equation modeling) is concerned with the increase of explained variance. The relationship between predictors and outcome variable are 0.253 (between compensation and engagement), and 0.419 (between promotion opportunity and engagement) respectively. All the predictor variables together explain 38.4 percent variances for the outcome variable (i.e., employee engagement). Therefore, the study reveals that two exogenous variables together explain 38.4 percent variance for the endogenous variable.

The structural model examines the relationship between the constructs to assess whether the path relationships are statistically significant or not (figure 2). The relationship between employee compensation and employee engagement (H1) is statistically significant $(\beta=0.253$; $\mathrm{t}$-value $=4.502$; $\mathrm{p}$-value $=0.000)$. When employees perceive that they are getting desired compensation package from the organization are expected to engage them with the organization. Employee compensation is one of the tools that has significant influence on the on the employees' engagement level at the workplace in the ready-made garment industry in Bangladesh. The earlier study in the 
context of Malaysia, Choo et al (2013) also find that handsome compensation package has significant influence on the employees' engagement level. Thus, it is evident from this study that employees' physical, mental and emotional devotion to work are influenced by the organization's handsome compensation bundle offered to the employees in the perspective of developing economy like Bangladesh.

Moreover, the relationship between employee promotion opportunity and employee engagement $(\mathrm{H} 2)$ is also found statistically significant $(\beta=0.419$; $t$-value $=7.624$; $p$ value $=0.000$ ). The smooth employee promotion opportunity at the workplace encouraged employees to be engaged more with the organization. Employees always expect positional advancement at workplace which has significant influence on their engagement level at work in the perspective of ready-made garment industry in Bangladesh. The previous study of Anitha (2014) in the Indian context reveals that employees' promotion opportunity at the workplace encourages them to be engaged with the organization. Therefore, it can be concluded that when employers ensure fair promotion practices in the organization it is expected to engage employees more with their work in the organization in the developing context like Bangladesh.

The predictive relevance $\left(\mathrm{Q}^{2}\right)$ of this study is examined through the value of construct cross-validated redundancy. The value of $\mathrm{Q}^{2}$ is more than zero signifies the model's predictive power and is valid for implication. The blindfolding procedure is administered for this purpose and found $\mathrm{Q}^{2}$ value 0.175 meaning that the model has adequate predictive relevance. The desired compensation package and promotion opportunity of the employees at the workplace together have 17.5 percent predictive power for the implication of this model in the context of ready-made garment industry in Bangladesh. Therefore, the model is expected to be used in the context of developing country as a means of increasing the employees' level of engagement in the organization.

\section{Conclusion}

The employee engagement concept becomes an important issue in the organization since it devotes employees at the workplace. In the developed context the influence of employee engagement has already been proved, however, the practitioners in the developing countries are still in dearth of conceptualizing this issue in their organization. In this study, it is evident that effective compensation and promotion policy have significant influence on the level of employee engagement in the 
organization. The business world today is highly competitive that demand devoted employees in the organization for its survival. Thus, enhancement of employee engagement is one of the solutions for ensuring organization's smooth operations. The appropriate HRM practices have significant influence of making employees engaged with the organization which ultimately accelerate the organization's success. Therefore, the practitioners and policy makers of the developing country expected to consider the findings of this model for engaging their employees to the organization.

This study has been conducted on the operational level employees of ready-made garment industry in Bangladesh, but some other studies may be conducted on mid level or upper level employees as well as on different contexts and environments for generalizing the relationship. Furthermore, this study explain only 38.4 percent variance for the employee engagement, therefore, other variables such as employee safety, perceived organizational supports, preferred working hours etcetera can be used as independent variable for increasing the expected variance.

\section{References}

Ahmed, S., Ahmad, F., \& Jaaffar, A. R. (2017). Human resource management practices as an antecedent of employee engagement: A case of a developing nation, International Journal of Bangladesh Society for Human Resource Management, 1(2), 1-14.

Albrecht, S. L. (2010), Handbook of Employee Engagement: Perspectives, Issues, Research, and Practice, Edward Elgar Publishing, Northampton, MA.

Anitha, J. (2014). Determinants of employee engagement and their impact on employee performance, International Journal of Productivity and Performance Management, 63(3), 308-323.

Aon Hewitt (2013). Trends in Global Employee Engagement Report, Lincolnshire, IL. Arakawa, D., \& Greenberg, M. (2007). Optimistic managers and the influence on productivity and employee engagement in a technology organization: Implications for coaching psychologists, International Coaching Psychology Review, 2(1), 78-89.

Choo, L. S., Mat, N., \& Al-Omari, M. (2013). Organizational Practices and employee engagement: A Case of Malaysian Electronic Manufacturing Firm, Business Strategy Series, 14(1), 3-10. 
Coetzee, M. \& Villiers, M. D. (2010). Sources of Job Stress, Work Engagement And Career Orientations Of Employees In A South African Financial Institution, Southern African, Business Review, 27, 57.

Cornish, J. (2002). Response problems in surveys: Improving response \& minimizing the load, Paper presented at UNSD Regional Seminar on 'Good Practices in the Organization and Management of Statistical Systems' for ASEAN countries, Yangon Myanmar, December 11-13.

Crawford, P., Brown, B., Kvangarsnes, M., \& Gilbert, P. (2014). The design of compassionate care, Journal of Clinical Nursing, 23(23/24), 3589-3599.

Export Promotion Bureau (2017). Annual Report 2017, Export Promotion Bureau of Bangladesh.

Fleck, S., \& Inceoglu, I. (2010). A comprehensive framework for understanding and predicting engagement. In: Albrecht, S. L. (Eds.), Handbook of Employee Engagement: Perspectives, Issues, Research, and Practice (pp. 31-61), Edward Elgar Publishing, Cheltenham.

Fleming, J. H., \& Asplund, J. (2007). Human sigma, Gallup Press, New York, NY.

Gagne', M., \& Bhave, D. (2011). Autonomy in the workplace: an essential ingredient to employee engagement and well-being in every culture. In: Chirkov, V. I., Ryan, R. M. and Sheldon, K. M. (Eds.), Human Autonomy in Cross-cultural Context: Perspectives on the Psychology of Agency, Freedom, and Well-being, (pp. 163-187), Springer, New York, NY.

Gallup Organization (2013). State of the Global Workplace: Employee Engagement Insights for Business Leaders Worldwide, Gallup, Washington, DC.

Hair, J. F. , Ringle, C. M,. \& Sarstedt, M. (2011). PLS-SEM: indeed a silver bullet, Journal of Marketing Theory and Practice, 19(2), 139-151.

Hair, J. F., Hult, G. T. M., Ringle, C. M., \& Sarstedt, M. (2014). A primer on partial least squares structural equation modeling (PLS-SEM), Thousand Oaks, CA: Sage.

Hinkin, T. R. (1995). A review of scale development practices in the study of organizations, Journal of Management, 21 (5), 967-989.

Iqbal, N., Karim, S. H. A., \& Haider, N. (2015). Impact of Rewards and Leadership on the Employee Engagement in Conventional Banking Sector of Southern Punjab, Arabian Journal of Business and Management Review, 5, 132.

Joshi, R. J., \& Sodhi, J. S. (2011). Drivers of employee engagement in Indian organizations, The Indian Journal of Industrial Relations, 47(1), 162-182. 
Kahn, W. A. (1990). Psychological conditions of personal engagement and disengagement at work, Academy of Management Journal, 33(4), 692-724.

Koskey, A. K. \& Sakataka, W. (2015). Effect of reward on employee engagement and commitment at Rift Valley Bottlers Company, International Academic Journal of Human Resource and Business Administration, 1(5), 36-54.

Krejcie, R. V., \& Morgan, D. W. (1970). Determining Sample Size for Research Activities, Educational and Psychological Measurement, 3, 607-610.

Luthans, F. \& Peterson, S. J. (2002). Employee engagement and manager selfefficacy: Implications for managerial effectiveness and development, Journal of Management Development, 21(5) (2002), 376-387.

Maslow, A. H. (1943). A theory of human motivation, Psychological Review, 50(4), 370-396.

Mokaya, S. O. \& Kipyegon, M. J. (2014). Determinants of Employee Engagement in the Banking Industry in Kenya; Case of Cooperative Bank, Journal of Human Resources Management and Labor Studies, 2014, 2(2), 187-200.

Nunnally, J. C., \& Bernstein, I. H. (1994). Psychometric theory (3rd ed.). New York, NY: McGraw-Hill, Inc.

Price, J. L., \& Mueller, C. W. (1986). Handbook of Organizational Measurement. Marshfield, MA: Pittman.

Rana, S., Ardichvili, A., \& Tkachenko, O. (2014). A Theoretical model of the antecedents and outcomes of employee engagement: Dubin's Method, Journal of Workplace Learning, 26(3/4), 249-266.

Roscoe, J. T. (1975). Fundamental Research Statistics for the Behavioural Sciences (2nd ed.), New York: Holt Rinehart \& Winston.

Schaufeli, W. B., \& Salanova, M. (2010). How to improve work engagement?, In: Albrecht, S. L. (Eds.), Handbook of Employee Engagement: Perspectives, Issues, Research and Practice, (pp. 399-415), Edward Elgar, Cheltenham.

Schaufeli, W. B., Bakker, A. B. \& Salanova, M. (2006). The measurement of work engagement with a short questionnaire: A cross-national study, Educational and Psychological Measurement, 66(4), 701-716.

Sekaran, U. (2006). Research methods for Business: A Skill Building Approach (4th ed.), Wiley India Pvt Limited, India.

Shuck, B. M., Rocco, T. S., \& Albornoz, C. A. (2011). Exploring Employee engagement from the employee perspective: Implication for HRD, Journal of European Industrial training, 35(4), 300-325. 
Shuck, B., \& Rocco, T. S. (2014). Human resource development and employee engagement. In: Truss, C., Delbridge, R., Alfes, K., Shantz, A. and Soane, E. (Eds), Employee Engagement in Theory and Practice, (pp. 116-130), Routledge, New York, NY.

Shuck, B., \& Wollard, K. K. (2010). Employee engagement and HRD: a seminal review of the foundations, Human Resource Development Review, 9(1), 89-110.

Solomon, M. \& Sridevi, M. S. (2010). Employee Engagement: The Key to Improving Performance, International Journal of Business and Management, 5(12), 89.

Teseema, M., \& Soeters, J. (2006). Challenges and prospects of HRM in developing countries: testing the HRM-performance link in Eritrean civil service, International Journal of Human Resource Management, 17(1), 86-105.

Vinzi, V. E., Lauro, C., \& Tenenhaus, M. (2003). PLS Path Modeling. (Working Paper). DMS - University of Naples, HEC - School of Management, Jouy-enJosas.

Wagner, R., \& Harter, J. K. (2006). The Great Elements of Managing (Vol. 1), The Gallup Organization, Washington, DC.

Wikipedia (2015, May 31). Bangladeshi RMG Sector, The free encyclopedia. Retrieve from: http://en.wikipedia.org/wiki/Bangladeshi_RMG_Sector

Wollard, K. K., \& Shuck, B. (2011). Antecedents to employee engagement: a structured review of the literature, Advances in Developing Human Resources, 13(4), 429-446.

Zhou, X., Yu, J. M. \& Cao, G. L. (2015). The Relationship between Career Growth and Employee Engagement: Based on the Mediating Effect of Organizational Commitment. Soft Science, 10, 88-91. 